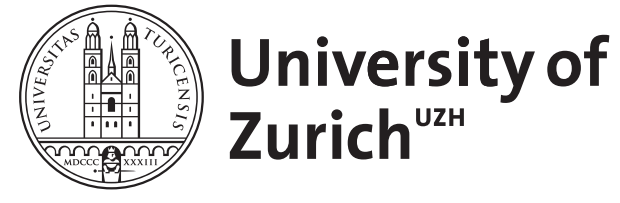

\title{
Expertise in Swiss mathematics instruction
}

\author{
Pauli, C ; Reusser, K
}

\begin{abstract}
This chapter draws on data and findings from several video studies to describe the quality of mathematics teaching in Switzerland. The focus is on features of instructional practice and quality as core components of classroom behavior that reflect the teacher's expertise in creating optimal learning opportunities. The didactic triangle is used as the basis for describing the profile of expertise in Swiss mathematics instruction in terms of three interdependent dimensions of instructional quality. A core element of this pofile can be identified in Swiss mathematics teachers' particular strengths in the culture of communication, support and relationships. Findings also paint a generally positive picture of the culture of teaching, learning and understanding (e.g., methods and choreography of teaching) in Swiss mathematics classrooms. However, the culture of objectives, materials and tasks proves to be rather average in international comparison in several respects (level of mathematical content, characteristics of the problems set and the way they are worked on in lessons). In particular, there seems to be room for improvement in the specific context of the didactics of mathematics (e.g., the level of cognitive and mathematical challenge)
\end{abstract}

DOI: https://doi.org/10.1007/978-1-4419-7707-6_1

Posted at the Zurich Open Repository and Archive, University of Zurich

ZORA URL: https://doi.org/10.5167/uzh-54971

Book Section

Published Version

Originally published at:

Pauli, C; Reusser, K (2011). Expertise in Swiss mathematics instruction. In: Liu, Y; Kaiser, G. Expertise in mathematics instruction: an international perspective. New York: Springer, 85-107.

DOI: https://doi.org/10.1007/978-1-4419-7707-6_1 


\title{
Expertise in Swiss Mathematics Instruction
}

\author{
Christine Pauli and Kurt Reusser
}

\begin{abstract}
This chapter draws on data and findings from several video studies to describe the quality of mathematics teaching in Switzerland. The focus is on features of instructional practice and quality as core components of classroom behavior that reflect the teacher's expertise in creating optimal learning opportunities. The didactic triangle is used as the basis for describing the profile of expertise in Swiss mathematics instruction in terms of three interdependent dimensions of instructional quality. A core element of this profile can be identified in Swiss mathematics teachers' particular strengths in the culture of communication, support and relationships. Findings also paint a generally positive picture of the culture of teaching, learning and understanding (e.g., methods and choreography of teaching) in Swiss mathematics classrooms. However, the culture of objectives, materials and tasks proves to be rather average in international comparison in several respects (level of mathematical content, characteristics of the problems set and the way they are worked on in lessons). In particular, there seems to be room for improvement in the specific context of the didactics of mathematics (e.g., the level of cognitive and mathematical challenge).
\end{abstract}

Keywords Quality of instruction · Mathematics education · Switzerland · Video studies · Instructional reform

This chapter on expertise in Swiss mathematics instruction was prompted by the findings of the Trends in International Mathematics and Science Study (TIMSS) and the OECD's Programme for International Student Assessment (PISA), which paint a thoroughly positive picture of mathematics instruction in Switzerland (Moser \& Notter, 2000; Moser, Ramseier, Keller, \& Huber, 1997; Zahner Rossier et al., 2004; Zahner Rossier \& Holzer, 2007). Swiss students at both lower and upper secondary level have performed very well in international assessments of mathematics achievement to date. Moreover, Swiss mathematics teachers seem able to achieve

C. Pauli $(\bowtie)$

Institute of Education, University of Zurich, Zurich, Switzerland

e-mail: cpauli@ife.uzh.ch 
good educational outcomes in a relatively positive and anxiety-free learning environment: Swiss students' self-confidence and interest scores have been found to be average or slightly above average; their anxiety scores, well below the OECD average (Zahner Rossier, 2005). Although there are doubtless numerous reasons for these encouraging findings, it seems reasonable to infer that mathematics instruction and teacher expertise play at least some role. This raises the question of what it is that characterizes the expertise of Swiss mathematics teachers.

The main focus of the current literature on teacher expertise is often on measuring and describing teachers' professional competence in terms of components of teacher knowledge and skills (Baumert \& Kunter, 2006; Besser \& Krauss, 2009; Blömeke, Kaiser, \& Lehmann, 2008; Kunter, Klusmann, \& Baumert, 2009). Teacher competence is seen as the first link in a chain of cause and effect running from teaching practice or quality of instruction via student learning to academic achievement and other cognitive and noncognitive outcomes (Pauli \& Reusser, 2009; Reinisch, 2009). In this chapter, in contrast, we focus on aspects of instructional quality. This approach is based on the idea that teacher expertise is manifested in the quality of classroom teaching practice. According to current theoretical models of learning and instruction, teaching offers a range of learning opportunities for student learning in the classroom (Fend, 1998; Helmke, 2009; Reusser \& Pauli, 1999). Whereas the provision of learning opportunities reflects the professional competence of the teacher (knowledge, skills, beliefs, motivation), students' actual learning outcomes also depend on the extent to which they recognize and are able to take advantage of these learning opportunities.

In this chapter, we therefore draw on expert ratings of videotaped lessons as well as on student ratings of aspects of instructional quality to describe instructional practice and quality in Swiss mathematics lessons. Furthermore, we make a theoretical distinction that has proved helpful in the assessment and description of instruction (Aebli, 1983; Messner \& Reusser, 2006; Oser \& Baeriswyl, 2001), distinguishing the surface level of lesson organization (e.g., methods, instructional scripts, lesson choreography) from the deeper level of quality of instruction (quality of teaching and learning processes, quality of teacher-student interaction). Drawing on video and questionnaire data obtained from both teachers and students in the context of several video studies, we describe Swiss mathematics instruction at both levels and thus develop a profile of the expertise of Swiss mathematics teachers (sections "Characteristics of Swiss Mathematics Instruction in International Comparison" and "Student and Expert Judgments of the Instructional Quality of Swiss Mathematics Teaching"). First, however, we describe the data sources available and provide some background information on the context in which the participating teachers work.

In section "The Role of Instructional Reform", we investigate the impact of innovations and reform initiatives on the thinking and practice of Swiss mathematics teachers. As research on teacher training has shown, teachers' beliefs about the processes of learning and instruction and about the role that students play in these processes are of fundamental importance in the implementation of reforms (Baumert \& Kunter, 2006; Reusser, Pauli, \& Elmer, 2011; Turner, Christensen, 
\& Meyer, 2009). We therefore take Hans Aebli's (1983) model of psychological didactics, which has been widely adopted in teacher training programs in the German-speaking part of Switzerland, as the starting point for our investigation of how a specific reform initiative - based on the ideas of progressive education (individualized learning, student orientation, and learner autonomy) - has influenced teaching practice. Finally, we summarize and systematize the findings presented in the chapter. By considering the strengths and weaknesses identified in terms of three dimensions of instructional quality, we develop a profile of teacher expertise from the didactic perspective.

\section{Data Sources}

Our main data source in this chapter is the TIMSS 1999 Video Study (Hiebert et al., 2003) and the Swiss Video Study that was embedded in it. Designed as a video survey (Stigler, 1998), the TIMSS 1999 Video Study aimed to document everyday classroom instruction in a variety of countries and, on this basis, to describe patterns of teaching practices within each country. There was a particular focus on comparing mathematics teaching in the United States and in those countries that showed comparatively high achievement on TIMSS assessments. To this end, representative samples of approximately 100 (Switzerland: 140) mathematics lessons each were videotaped in Australia, the Czech Republic, Hong Kong, the Netherlands, Switzerland, and the United States. Numerous features of both the structure of lessons (e.g., forms of interaction, activities) and the mathematical content covered (e.g., characteristics of the problems set and the way these problems were worked on in the lesson) were analyzed. Japanese mathematics lessons collected for the TIMSS 1995 Video Study were re-analyzed as part of the TIMSS 1999 Video Study (Hiebert et al., 2003).

In Switzerland, the TIMSS 1999 Video Study was extended within the context of the Swiss Video Study (Reusser, Pauli, \& Waldis, 2010). ${ }^{1}$ In addition to the video recordings obtained within the TIMSS 1999 Video Study, the Swiss database includes extensive survey data (teacher and student questionnaires), a cognitive abilities test, and mathematics assessments, embedded in a longitudinal design. In the Swiss Video Study, the video data were reanalyzed in a number of respects. In particular, the instructional quality of the lessons was assessed. The same quality evaluations were conducted in a subsample of the German mathematics lessons videotaped for the TIMSS 1995 Video Study (Clausen, Reusser, \& Klieme, 2003), thus making it possible to compare the quality of German and Swiss mathematics lessons.

\footnotetext{
${ }^{1}$ This research was funded by the Swiss National Foundation (SNF grant 4033-054871), the Ecoscientia Foundation (Zurich, Switzerland), and CORECHED (Swiss Conference for the Coordination of Educational Research).
} 
This chapter also draws on the findings of a video study investigating mathematics instruction in Germany and Switzerland (Klieme, Pauli, \& Reusser, 2009) that was conducted in collaboration between a German research group (principal investigator: Eckhard Klieme) and our Swiss research group (principal investigators: Kurt Reusser, Christine Pauli). One of the features that distinguishes this GermanSwiss video study, which was based on a sample of 20 classes in each country, from the Swiss Video Study described above is that more than one lesson delivered by each teacher was recorded (two lesson units; five lessons in total), and that the content taught was standardized. The study also included a teacher survey; approximately 150 mathematics teachers in each country reported on aspects such as their self-perceptions and experience of teaching.

The data provided by the TIMSS Video Study and the German-Swiss Video Study make it possible to determine where Swiss mathematics teachers stand in international comparison on various indicators of teaching expertise.

\section{Characteristics of Swiss Mathematics Instruction in International Comparison}

Before drawing on selected findings from the TIMSS 1999 Video Study and the Swiss Video Study to describe key characteristics of Swiss mathematics instruction, we outline some particularities of the Swiss teaching context.

One defining characteristic of the Swiss context is that Switzerland has three main language regions. ${ }^{2}$ These regions differ not only in the language of instruction (German, French, Italian), but also in certain aspects of their education systems, including pre- and in-service teacher training. As a federation of 26 cantons, Switzerland does not have a centralized education system. Most cantons in the German- and French-speaking areas (but not in the Italian-speaking areas) implement a three-track secondary system based on academic ability. Until a few years ago, many cantons ran different training programs for candidate teachers aspiring to teach in the different tracks (i.e., school types). Working conditions also differ across the three tracks, as reflected in the data from the representative sample of the TIMSS 1999 Video Study. For example, under 5\% of the teachers at the least academically demanding school type in the German-speaking part of Switzerland (most of whom were all-rounders responsible for teaching several subjects) had at least 2 years' university-level training in mathematics (compared with $67 \%$ of teachers in the intermediate school type and $100 \%$ of teachers in the most academically demanding school type). A similar picture emerges for the French-speaking part of the country. In contrast, the great majority (at least $85 \%$ ) of the teachers in the Italian-speaking part of the country studied mathematics at university.

\footnotetext{
${ }^{2}$ The three language regions and all school types were adequately represented in the Swiss sample of the TIMSS 1999 Video Study $(N=140)$. It was not possible to include the country's fourth language (Romansh), which is spoken only in a small area.
} 
What then are the surface-level characteristics of mathematics instruction in Switzerland? Analyses of data from the TIMSS 1999 Video Study make it possible to examine how Switzerland compares with other high-achieving countries and the United States in terms of lesson organization, instructional practices, and the mathematical content of lessons. With the exception of Japan, however, these analyses have revealed many similarities in mathematics teaching across all countries examined, including the United States. In other words, Swiss mathematics lessons did not deviate from the general international pattern of teaching practices that emerged from these analyses. For example, the findings of the TIMSS 1999 Video Study indicated that mathematics teaching in Switzerland is (also) dominated by problems with a low level of complexity that can be solved within a few minutes by repeating known procedures; most of these problems have no relevance to practical applications or to students' everyday lives. Challenging mathematical activities such as constructing mathematical proofs or exploring, presenting, and discussing multiple solution methods were something of a rarity in the Swiss sample.

Analyses examining not only the frequency or duration, but the sequencing or choreography of activities over the course of a lesson (Oser \& Baeriswyl, 2001) revealed a somewhat higher level of variability in the Swiss sample relative to the other countries (Givvin, Hiebert, Jacobs, Hollingsworth, \& Gallimore, 2005). In international comparison, Swiss mathematics instruction thus seems to be characterized less by the presence of certain lesson features or by a clearly identifiable pattern of teaching practices, but by greater variability across lessons. It seemed reasonable to hypothesize that this diversity might be attributable to systematic differences across the country's three main language regions. The empirical data did not support this hypothesis, however. With few exceptions, the international video coding system revealed no systematic differences across the language regions in the features of teaching investigated (Pauli \& Reusser, 2010b).

Instead, the function of the lesson in the learning process (introductory vs. follow-up lesson) proved to be relevant. Surveys of the participating teachers (Pauli $\&$ Reusser, 2010a) and of experts in pre- and in-service teacher training revealed that - from both the teacher and the expert perspective - the arrangement of mathematics lessons depends on whether new material is introduced (introductory lesson) or known material is consolidated and practiced (follow-up lesson). Data obtained through the international teacher questionnaire made it possible to categorize the videotaped lessons as either introductory or practice/follow-up lessons. As expected, the two lesson types differed in some aspects of teaching; for example, there was more independent student work in practice and follow-up lessons than in introductory lessons. The distinction between introductory and follow-up lessons - which was, incidentally, also observed to a certain extent in sequences of mathematics lessons from the United States, Japan, and Germany, although in smaller samples (Clarke et al., 2007) - can be interpreted as indicating that Swiss teachers plan their lessons with a view to the different stages of the learning cycle, not all of which can generally be covered in a single lesson (Aebli, 1983, p. 276). We return to this "learning process orientation" as a defining characteristic of Swiss mathematics teaching below. 
A certain diversity of instructional choreographies was also found within the two lesson types, as an analysis of lessons in the German-speaking part of the country showed (Hugener \& Krammer, 2010). This finding is reflected in the data of the teacher survey included in the Swiss Video Study. Based on the findings of the TIMSS 1995 Video Study, Stigler and Hiebert (1999) developed the idea of culture-specific instructional scripts. The Swiss Video Study sought to assess these scripts through an open-ended question in the teacher questionnaire asking participants to describe the typical structure of an everyday mathematics lesson (or of an introductory and a follow-up lesson). Content analysis of these descriptions (Pauli \& Reusser, 2010a) revealed that, for introductory lessons, most teachers in all three language regions described a pattern of instruction that corresponds to the typical structure of fragend-entwickelnder Unterricht, a kind of instructional dialogue between teacher and students. However, some $27 \%$ of descriptions in all three language regions revealed a second pattern, which can be labeled "exploratory/discursive". The descriptions of a typical follow-up lesson also revealed two main lesson types. Whereas most teachers described a mix of individual and teacher-directed collective work on problems and teacher-guided discussion of solutions, $12 \%$ of teachers described an alternative approach, namely individualized instruction with personal learning plans.

Overall then, the data indicate that there is no single teaching script dominating Swiss mathematics lessons. Rather, Swiss teachers seem to draw on different instructional scripts, as further survey data confirm (Pauli \& Reusser, 2003; Stebler $\&$ Reusser, 2000). These data indicate that it is less the language region or the country in which a teacher works that determines the didactic approach taken, than the degree to which innovations and reform initiatives are implemented in lessons (see also Blömeke \& Müller, 2008) in correspondence with the teacher's personal beliefs about teaching and learning (see section "The Role of Instructional Reform"). As a federal state, moreover, Switzerland does not have a national curriculum or centralized teaching strategies. Rather, teachers have considerable freedom in their choice of methods and approaches. Apart from the broad educational goals laid out in cantonal curricula and a certain amount of compulsory teaching material, it is left largely to individual teachers to decide whether and how to integrate new teaching methods and reforms into their classroom practice.

This considerable freedom of discretion was not only apparent in the teacher survey data and in the videotaped mathematics lessons, but also reflected in what Swiss experts in mathematics teaching and teacher training expected to observe in everyday mathematics classrooms in Switzerland. In group interviews conducted in the run-up to the TIMSS 1999 Video Study, experts were unable to compile a single "hypothesized country model" describing mathematics instruction in Switzerland (Hiebert et al., 2003, pp. 209-211). Instead, they expected most lower secondary mathematics teachers in the country to have a rather traditional, teacher-directed instructional style, but another pattern of lessons to be seen in reform-oriented classrooms. Both approaches were seen to have a place. One advantage of this tolerance of different methods is doubtless the pragmatic approach to instructional reform that can be observed throughout Switzerland, which prevents the premature, overly radical, or flawed implementation of proposed reform models (see section "The Role 
of Instructional Reform"). However, one potential disadvantage is the associated lack of commitment to the systematic development of instruction. For example, it is currently left largely to teachers to decide whether and to what extent to implement individualized forms of teaching in their lessons. Given that the heterogeneity of school classes is set to increase in the coming years, this model is bound to reach its limits. New forms of and commitments to training and instructional development will thus be required.

\section{Student and Expert Judgments of the Instructional Quality of Swiss Mathematics Teaching}

Instructional research has repeatedly shown that it is less the surface features of instruction that determine students' learning outcomes than the deeper level aspects of instructional quality (see, e.g., Brophy, 2006; Helmke, 2009; Helmke \& Weinert, 1997; Klieme \& Rakoczy, 2008; Seidel \& Shavelson, 2007). The cognitive activation of students, a supportive learning environment or student-oriented teaching style, clarity and structure of presentation, and efficient classroom management have been identified as particularly important quality dimensions (Helmke, 2009; Klieme et al., 2009; Kunter et al., 2006; Lipowsky et al., 2009). In this section, we examine the extent to which these aspects of instructional quality are apparent in Swiss mathematics classrooms. To this end, we draw on the expert and student ratings obtained for a representative sample of 140 mathematics lessons in the context of the Swiss Video Study.

Using 4-point rating scales, the participating students assessed various aspects of instructional quality; their responses were collated to form six scales: clarity and structure, classroom management, individual support, cognitive activation, social climate and student autonomy. As the analyses show, lower secondary students' evaluations of their mathematics instruction were generally positive across the three language regions of Switzerland examined (Fig. 1). The only instructional feature to receive less favorable ratings was "scope for student autonomy" (Waldis, Grob, Pauli, \& Reusser, 2010b).

The question arises whether these positive student ratings are attributable to the quality of instruction - that is, to the expertise of Swiss mathematics teachers or whether they are more a reflection of Swiss students' fundamentally positive attitudes toward learning mathematics. Various findings indicate that most Swiss students have a positive approach to learning mathematics. In the Swiss Video Study, for example, open-ended items in the student questionnaire tapping quality of motivation in mathematics lessons painted a thoroughly positive picture: Both in grade 8 and at the second assessment in grade 9, Swiss students tended to show a self-determined motivational orientation. In particular, they emphasized the practical value of mathematics (Buff, Reusser, \& Pauli, 2010). The student questionnaire further assessed mathematics interest on an 8-item scale and revealed positive ratings overall, although the gender differences known from the literature were apparent (with girls showing less interest), as were differences across school types depending on the language region (Waldis, Grob, Pauli, \& Reusser, 2010a). In 


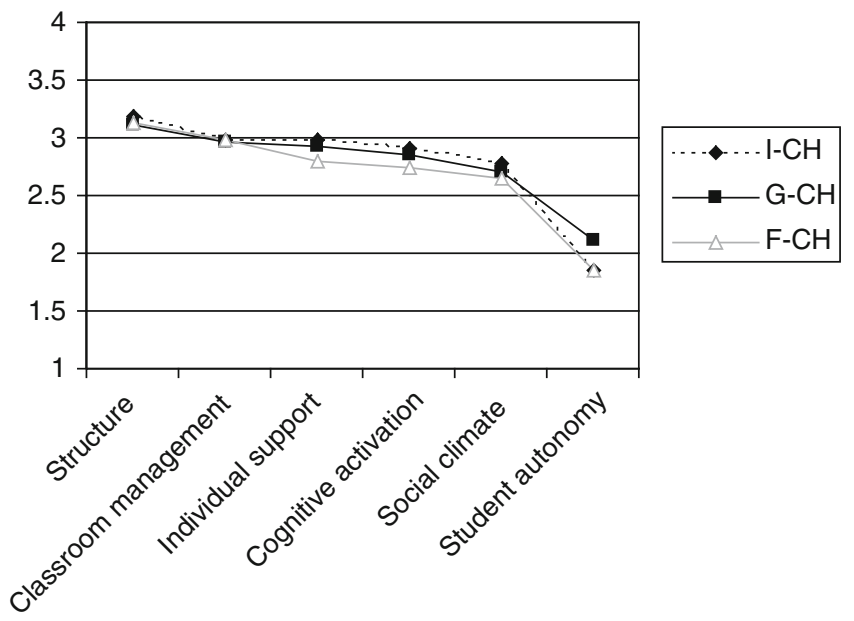

Fig. 1 Mean student ratings of instructional quality. I-CH: Italian-speaking Switzerland $(n=27)$, G-CH: German-speaking Switzerland $(n=74)$; F-CH: French-speaking Switzerland $(n=39)$. Data base: Representative sample of 140 Swiss lessons (and classes) from TIMSS 1999 Video Study (see also Waldis et al., 2010b, p. 189)

the German-speaking part of Switzerland, for example, students attending the least academically demanding school type reported higher interest than did their peers in the most academically demanding school type.

There is thus much evidence to suggest that Swiss students' positive perceptions of their instruction also reflect a generally positive attitude to learning mathematics. However, this does not exclude the possibility that "objectively" measurable aspects of the quality of instruction and of teacher expertise also contribute to the favorable student ratings. Rather, a reciprocal relationship can be assumed.

As Fig. 2 shows, observer ratings of instructional quality in the videotaped mathematics lessons were good to very good (clarity/structure) for all features assessed: clarity/structure, classroom management, cognitive activation, and student orientation (see Waldis et al., 2010b).

Overall, both students and observers evaluated the quality of Swiss mathematics instruction favorably. The different school types revealed specific learning cultures with respect to the "scope for student autonomy" and "cognitive activation," with the least academically demanding schools granting greater scope for student autonomy within the German- and Italian-speaking areas and the most academically demanding schools offering a higher level of cognitive activation within the German- and French-speaking areas (not shown in Figs. 1 or 2). In the Italian-speaking region, where students are not tracked to separate school types, but streamed within schools according to their ability in certain subjects, no such pattern emerged. ${ }^{3}$

\footnotetext{
${ }^{3}$ It would go beyond the scope of this chapter to report the results for different school types; for details, see Waldis et al. (2010b).
} 


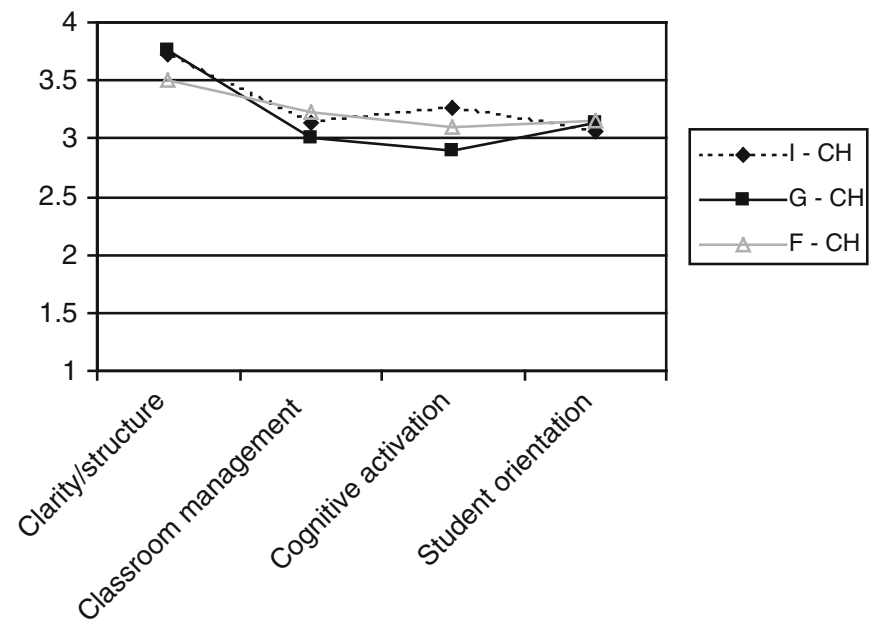

Fig. 2 Mean expert ratings of instructional quality. I-CH: Italian-speaking Switzerland $(n=27)$, G-CH: German-speaking Switzerland $(\mathrm{n}=74)$; F-CH: French-speaking Switzerland $(n=39)$. Data base: Representative sample of 140 Swiss lessons from TIMSS 1999 Video Study (see also Waldis et al., 2010b, p. 196)

The profile of Swiss mathematics instruction can be further defined by comparing observer ratings of the quality of instruction in Swiss and German mathematics classrooms. Data from a subsample of 30 Swiss lessons (from the TIMSS 1999 Video Study) and 30 German mathematics lessons derived from the TIMSS 1995 Video Study (Clausen et al., 2003) showed that the Swiss lessons were rated higher than the German lessons in terms of classroom management, individualization, and student-oriented teaching, but ratings of cognitive activation and clarity/structure did not differ. This general pattern of results was echoed in the later binational video study of mathematics instruction in 20 German and 20 Swiss classes (Klieme et al., 2009). Here again, the Swiss lessons scored higher on some features indicative of motivationally supportive instruction, namely student perceptions of social relatedness and autonomy support and observer ratings of room for autonomy (Rakoczy, 2008). ${ }^{4}$ In contrast, the German students perceived a higher level of competence support and, to some extent, the observers evaluated the cognitive demands of the German lessons to be higher (p. $187 \mathrm{ff}$.).

Interestingly, these findings are very much in line with an evaluation of instructional quality in three Swiss mathematics lessons selected by the project management of the TIMSS 1999 Video Study as "typical." In group interviews conducted in four countries (Australia, Czech Republic, Hong Kong, United States), international expert groups agreed that these three lessons showed a high level of teacher

\footnotetext{
${ }^{4}$ Note that the same instruments (student questionnaire, rating inventory) were not used in this study.
} 
direction, a high level of student involvement, and a generally positive atmosphere. However, the expert groups did not agree on the quality of the mathematical content (Givvin, Jacobs, Hollingsworth, \& Hiebert, 2009; Petko, Krammer, Pauli, \& Reusser, 2010).

Overall, the findings summarized here suggest that Swiss mathematics teachers have particular strengths in the domain of student-oriented teaching and creating a supportive learning atmosphere, especially where granting students autonomy in the learning process, individualization, and good classroom relations are concerned. However, the cognitive demands of Swiss mathematics instruction and the level of cognitive activation achieved are no higher than average.

\section{The Role of Instructional Reform}

One important component of teachers' professional competence is the ability to develop their instructional practice and to implement reforms successfully. Beliefs about teaching and learning play an important role here (Philipp, 2007; Richardson \& Placier, 2001; Turner et al., 2009). In this section, we investigate the impact of a specific reform initiative on mathematics instruction in the German-speaking part of Switzerland. ${ }^{5}$ This initiative is characterized by a revised understanding of the role that students play in the learning process.

Teacher training in the German-speaking part of Switzerland has traditionally been strongly influenced by the model of "psychological didactics" proposed by Hans Aebli, a student of Jean Piaget (Aebli, 1951). Aebli's standard work on the "basic forms of teaching" (Aebli, 1961, 1983) has been a core component of many teacher training programs for decades. One key element of Aebli's approach is its focus on students' learning processes (Messner \& Reusser, 2006, pp. 67-68). From Aebli's perspective, it is less the surface features of instruction that are decisive for lesson planning and hence the quality of instruction, than the deeper level structures - that is, the extent to which instruction succeeds in enabling the intended learning processes. The relatively large variation in teaching methods observed in Swiss mathematics classrooms, and the distinction of introductory and follow-up lessons (see section "Characteristics of Swiss Mathematics Instruction in International Comparison"), can be seen as evidence that the thinking and practice of many Swiss mathematics teachers is shaped by this approach.

Aebli's approach was founded on a constructivist understanding of student learning, based on Piaget's constructivist epistemology and theory of cognitive development. Like Piaget, Aebli maintained that learners actively construct and transform knowledge by integrating new information and experience into what they have previously come to understand, and by revising and reinterpreting old

\footnotetext{
${ }^{5}$ Because the reform situation differs across the three language regions in certain respects (e.g., differing models of reform, use of terminology, strategies of instructional development and in-service training, etc.), we restrict our analyses to data from the German-speaking part of the country.
} 
knowledge in order to reconcile it with the new. But whereas Aebli agreed with Piaget on the active role of the learner in the learning processes, unlike Piaget he attributed a central role to the guidance and mediation of learning through interaction with the teacher. This is expressed in his model of "problem-based knowledge construction," a teacher-guided problem-solving approach with the goal of achieving deep and flexible understanding (see also Pauli, Reusser, \& Grob, 2007).

However, models of student-oriented instruction rooted in progressive education in the German tradition (Reformpädagogik) also have a long tradition in Switzerland. These models emphasize student autonomy and co-determination of learning arrangements. In the 1990s, these ideas saw a significant renaissance in a teaching reform initiative that emerged essentially from classroom practice and became known as "Extended Forms of Teaching and Learning" (ETL). This reform model strives to extend the repertoire of teaching methods, focusing primarily on the organization of learning activities, and aiming to give students more opportunities for co-determination and individualized learning. Typical learning arrangements are individualized weekly learning plans, project teaching, and workstations (Croci, Imgrüth, Landwehr, \& Spring, 1995; Pauli et al., 2007). Whereas these forms of teaching and learning primarily aim to provide organizational and procedural autonomy support (Stefanou, Perencevich, DiCintio, \& Turner, 2004), the aspect of cognitive autonomy support has attracted increasing attention in recent years, especially in the context of mathematics teaching. Against this background, the ETL model also calls for more opportunities for students to engage in independent problem solving and higher order thinking (see also Affolter et al., 2006).

The question arises of how this reform model has been received and implemented by mathematics teachers in the German-speaking part of Switzerland. To assess how familiar these teachers are with didactic principles and reform initiatives, the teacher questionnaire administered to the teachers of the TIMSS 1999 Video Study sample in the context of the Swiss Video Study included a question asking how often they organized their lessons according to three didactic principles: (1) operative didactics ([guided]) problem-based knowledge construction; e.g., Aebli, 1983; Wittmann, 1981); (2) the genetic-socratic exemplary approach (e.g., Wagenschein, 2008) and (3) the model of extended forms of teaching and learning (ETL). As Fig. 3 shows, the ETL model proved to be well known and frequently implemented in the German-speaking mathematics classrooms of the TIMSS 1999 Video Study sample; only $2 \%$ of teachers stated that they were unfamiliar with the model. More than $41 \%$ stated that they "frequently" or "almost always," and 52\% that they "occasionally," taught according to the principles of ETL. There was somewhat less awareness and implementation of operative didactics; nevertheless, 39\% of teachers stated that they "frequently," and $22 \%$ that they "occasionally," taught according to this principle. Most teachers were also familiar with the genetic-Socratic approach, but its implementation in the classroom was much more limited.

Given that a large group (41\%) of teachers stated that they frequently or almost always taught according to the principles of ETL, it was interesting to examine what distinguishes the instruction of these reform-oriented teachers from that of 


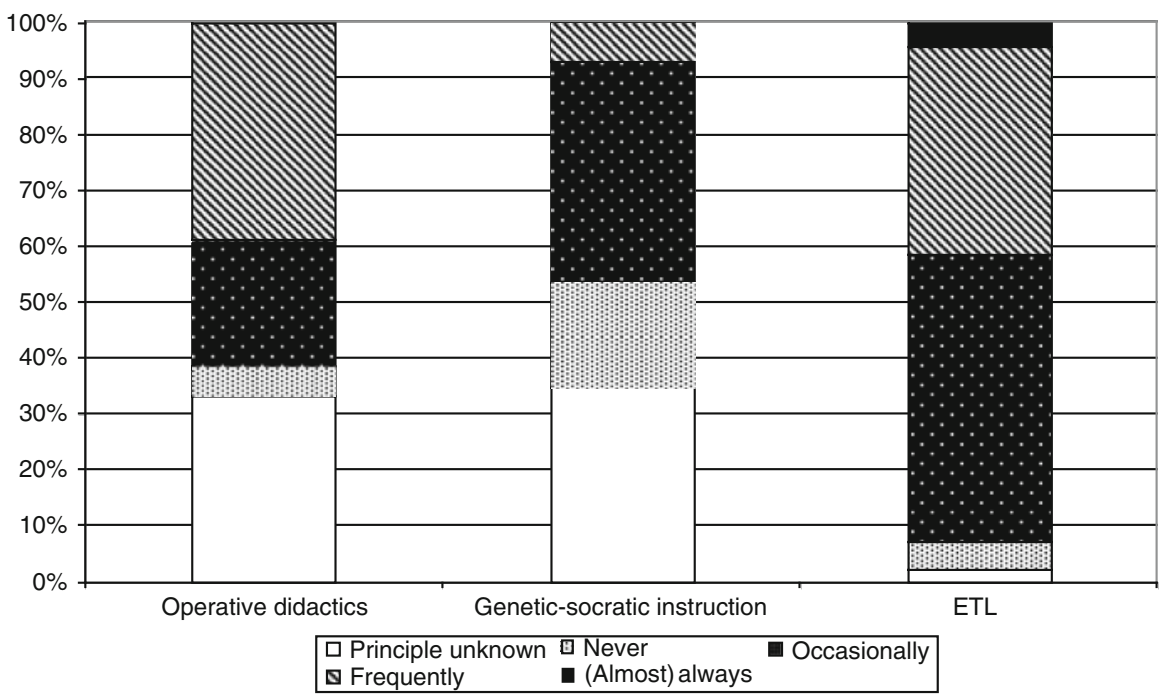

Fig. 3 Teacher awareness and implementation of didactic principles $(N=66$; teachers of Germanspeaking areas of Switzerland, based on the TIMSS 1999 Video Study sample). Operative didactics: (guided) problem-based knowledge construction (Aebli, Wittmann); genetic-socratic exemplary approach (Wagenschein); ETL model: reform model of extended forms of learning and teaching

their more traditionally oriented colleagues. This question was addressed in a series of steps, drawing on data from both teacher self-reports and student and observer ratings.

Based on the teacher self-reports, the classroom practice of reform-oriented and traditionally oriented teachers was first compared in terms of aspects of instruction and social interaction. Specifically, teachers were given a list of 32 forms of teaching and learning and asked to state the frequency with which each featured in their own practice (Pauli \& Reusser, 2010a; Pauli, Reusser, Waldis, \& Grob, 2003). For those forms of teaching and learning characteristic of the ETL model (e.g., weekly learning plans, workstations, individual guidance), a significant difference in the expected direction was found between reform-oriented and traditionally oriented teachers, with higher levels of implementation in reform-oriented classrooms (Pauli et al., 2003). However, few differences emerged in the forms of teaching and learning typical of traditional instruction. Figure 4 compares selected forms of instruction. In addition to the form of the teacher-led instructional dialogue that is typical of traditional instructional practice, the figure presents findings for two forms of instruction representing the aspect of granting students scope for self-directed learning that is central to the ETL model (weekly learning plan, workstations), and two forms of instruction that are characteristic of reform efforts in the specific context of mathematics (discovering solution methods, discussing solution methods).

Although the distribution of the teaching practices "weekly learning plan" and "workstations" differed significantly in the expected direction, there were no 


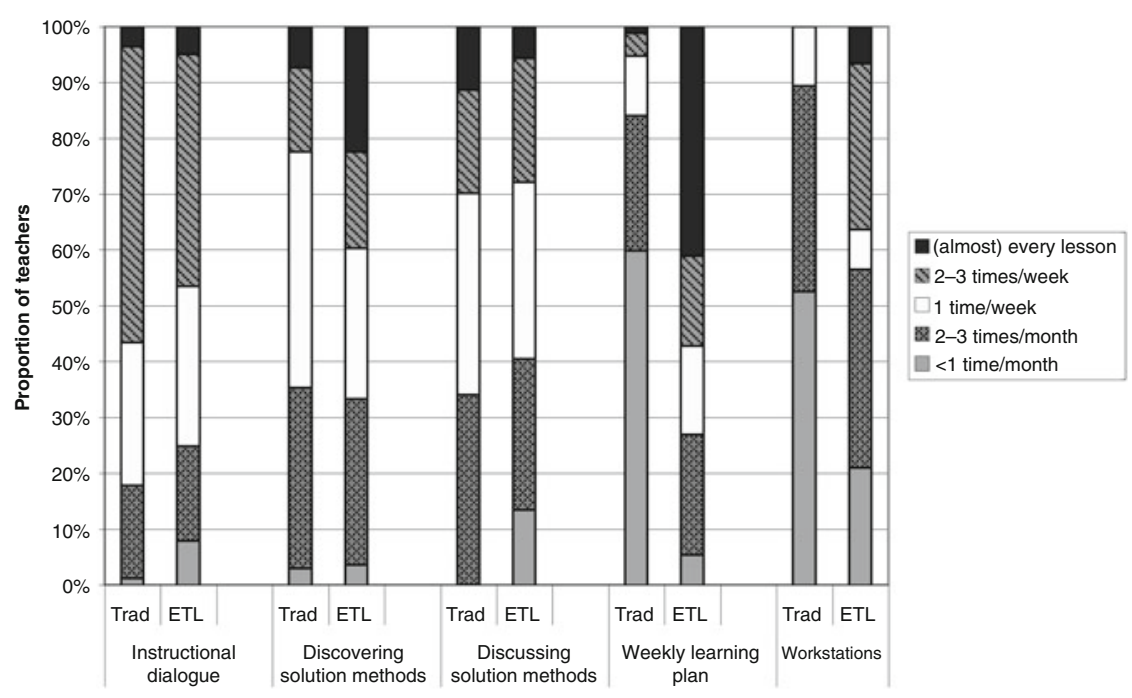

Fig. 4 Comparison of the frequency of implementation of instructional methods by traditionally oriented ("Trad.", $n=38$ ) and reform-oriented ("ETL", $n=28$ ) teachers in the German-speaking areas of Switzerland, based on the TIMSS 1999 Video Study sample. Significant differences emerged for weekly learning plan: $\chi^{2}(4, N=66)=25.49(p=0.000)$ and workstations: $\chi^{2}$ $(4, N=66)=12.23(p=0.016)$. No significant differences were found for the other methods

statistically significant differences between the reform-oriented and the more traditional teachers in the other forms of teaching and learning. These findings indicate that, in the teachers' self-conceptions, the practice of ETL is characterized primarily by creating more opportunities for self-regulated learning, and that there is less of an emphasis on discursive approaches to mathematical problems. Indeed, further analyses showed that there was no systematic relationship between the teacher-reported frequency of these two reform-oriented teaching practices (Pauli et al., 2007) or between reform-oriented instructional practice in terms of the organization of learning activities (opportunities for self-directed learning) and constructivist-oriented beliefs about teaching and learning. Interestingly, the reform-oriented teachers did not differ significantly from their more traditional colleagues in the frequency of teacher-led instructional dialogue, which plays a major role in Aebli's approach. The proportion of reform-oriented teachers who facilitated an instructional dialogue less than once a week is also relatively small at 25\% (traditional teachers: $18 \%$; see Fig. 4). These findings indicate that the ETL reform model does not mean a radical switch to open forms of instruction, but rather a broader spectrum of teaching practices at the organizational level, creating more opportunities for self-directed and individualized learning. This does not necessarily include exploratory and discursive approaches to mathematical problems.

Another interesting question is whether reform-oriented teaching practices influence student perceptions and expert ratings of instructional quality. Analyses indicate that this is indeed the case. Students and experts rated reform-oriented 
teachers significantly higher on various dimensions of instructional quality (cognitive activation, student orientation, clarity and structure), and students reported higher levels of positive emotional experience (Pauli et al., 2007, 2003). However, these findings were not reflected in the development of students' interest and achievement over the course of a school year, where neither a positive nor a negative effect was observed (Pauli et al., 2007, 2003).

Based on the international video analyses and on further analyses conducted in Switzerland, it was also possible to examine how the quality differences detected were reflected in observable features of teaching practice. The international analyses revealed few, rather weak relations between teacher orientation and classroom practice. Less whole-class work was observed in the reform-oriented teachers' lessons, but there were no significant differences in the culture of tasks (i.e., the quality of mathematical content or the characteristics of the problems set and the way they were worked on in the lesson). In other words, the reform-oriented teachers' lessons were also dominated by repetitive, low-complexity tasks that could be solved by applying known procedures. More challenging mathematical activities were rarely observed (Pauli, Reusser, \& Grob, 2010).

However, differences between the two teacher groups were found for classroom interaction and learning support, as a further analysis of the Swiss sample showed (Krammer, 2009). A detailed analysis of the activities and interactions occurring in phases of independent student work showed that reform-oriented teachers invested significantly more time in cognitively activating forms of individual learning support (i.e., feedback that encouraged students to continue thinking independently) and less time in evaluative feedback (feedback on the accuracy of task completion). In addition, their students had more opportunity to cooperate during phases of independent student work. In sum, Krammer's (2009) findings indicate that, relative to their more traditionally oriented colleagues, reform-oriented teachers dedicate more lesson time to independent student work (either individually or in pairs/groups), and that this time is used productively to guide and support individual learning processes.

In summary, the analyses presented indicate that instructional reform initiatives play a notable and generally positive role in lower secondary mathematics instruction in Switzerland. In particular, the ETL model, which is informed by the tradition of progressive education, is widely known and its impact on instructional practice and quality is perceptible to both students and observers. What characterizes this reform model is that (in contrast to some concepts of open education) it does not prescribe a radical transformation of traditional, teacher-directed instruction, but strives to extend the repertoire of teaching methods in terms of both the organization of learning activities (e.g., weekly learning plans) and ways of encouraging and supporting student learning processes. The present analyses of data from several video studies suggest that the ETL model is currently being implemented primarily at the organizational level, with students being given greater scope for autonomy through weekly learning plans and cognitively activating individualized learning support. There is room for improvement in lesson content in terms of the level of 
cognitive and mathematical challenge, the quality of the problems set, and the way they are worked on in lessons - that is, in the deep structure of teaching and learning processes.

\section{Conclusion}

This chapter drew on data and findings from several video studies to describe the quality of mathematics teaching in Switzerland. The chapter focused on features of instructional practice and quality as core components of classroom behavior that reflect the teacher's expertise in creating optimal learning opportunities. Despite this focus on instruction, it is important to remember that observable teacher behavior and instructional quality are influenced by multiple factors at different levels of the education system, as well as by the characteristics of those on the "uptake" end - that is, the students and their parents. These relationships, which are articulated in the model of the provision and uptake of learning opportunities (Fend, 2002, 2008; Helmke, 2009; Reusser \& Pauli, 2003), need to be taken into consideration when interpreting the present findings on expertise in Swiss mathematics instruction.

In terms of the students and parents on the "uptake" end of learning opportunities, for example, Swiss mathematics teachers have to date benefited from relatively favorable conditions. A survey of German and Swiss mathematics teachers embedded in the German-Swiss video study showed that Swiss teachers seem to be aware of this fact (Lipowsky, Thussbas, Klieme, Reusser, \& Pauli, 2003). Their ratings of student and parental interest were fairly high; their ratings of student and parent appreciation of their work, very high. Interestingly, the teacher ratings mirrored the difference in student interest ratings found across school types in the Germanspeaking part of Switzerland (see section "Student and Expert Judgments of the Instructional Quality of Swiss Mathematics Teaching"): Overall, the teachers rated students at the least academic school type to show much higher interest in mathematics than students in the most academically demanding school type. The opposite pattern of results was found in German teachers, whose overall ratings were also lower than those of their Swiss colleagues. A similar pattern emerged for teacher self-perceptions. For example, Swiss mathematics teachers had higher self-efficacy than their German colleagues, and German teachers reported more stress than their Swiss colleagues, with the least favorable constellation again being found in German teachers working in the least academic track of the [three-tiered] German secondary system, the Hauptschule. These findings indicate that teachers in Switzerland, even at the least academically demanding schools, feel able to practice their profession to the desired level. In the terms of the model of the provision and uptake of learning opportunities, this too can be seen as a reciprocal relationship.

In the following, we use the model of the didactic triangle as the basis for presenting our conclusions on expertise in Swiss mathematics instruction. In this model, the teacher, students, and content correspond to the points of the triangle describing the 


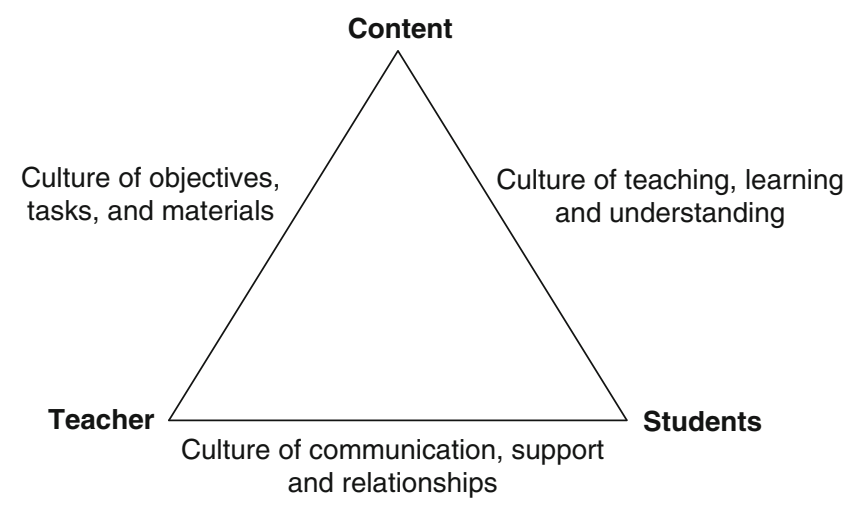

Fig. 5 Didactic triangle (Reusser, 2008, 2009)

teacher's scope of practice in the classroom (Reusser, 2008, 2009). The three sides of the triangle define three interdependent dimensions of instructional quality, namely the culture of objectives and materials; the culture of teaching, learning, and understanding; and the culture of communication, support, and relationships (see Fig. 5). Considering the empirical findings presented above in terms of these three quality dimensions can help to build up a detailed profile of expertise in Swiss mathematics instruction.

A core element of this profile can be identified in Swiss mathematics teachers' particular strengths in the culture of communication, support, and relationships, as reflected by the positive ratings of instructional quality given by both students and independent observers in the video studies and as confirmed by the comparison of observer ratings of German and Swiss mathematics lessons (Clausen et al., 2003). Data obtained through the PISA 2000 student questionnaire point in the same direction: Swiss students rated their teachers to be supportive and, in particular, the quality of teacher-student relations to be high, but perceived levels of pressure to achieve to be relatively low (Klieme \& Rakoczy, 2003, p. 344). The findings that Swiss students reported anxiety levels below the OECD average in mathematics (see Introduction) and higher wellbeing in school than, for example, German students (Fend, 1998) can be attributed to this generally positive culture of communication, support, and relationships. However, these findings should not be interpreted as indicating that there is no scope for teacher improvement in this dimension of instructional quality. For example, Krammer's (2009) analyses identify a need for enhancement of adaptive individual learning support. Overall, a rather low proportion of the individual learning support provided was evaluated to be cognitively activating (i.e., to stimulate further thought). This proportion was significantly higher in the lessons of reform-oriented teachers than in those of their traditionally oriented colleagues, highlighting the potential of the ETL model as a platform for adaptive instruction. 
The findings presented also paint a generally positive picture of the culture of teaching, learning and understanding - in other words, the actual process of learning and its choreography - in Swiss mathematics classrooms. The various video analyses give the impression of well-managed lessons with few disruptions, guided primarily by the teacher, but also involving a fairly high proportion of independent student work in international comparison. Although a form of instructional dialogue also plays a key role in Swiss mathematics instruction, the video analyses reveal a notable variety of teaching practices and methods. One reason for this is that Swiss teachers deliberately include phases of consolidation and practice in their lessons, as reflected in the distinction between introductory and followup lessons observed in both the instructional scripts described by teachers and the video recordings. Another reason is the relatively widespread implementation of the ETL reform model. This model is characterized by its combination of traditional, teacher-directed forms of instruction and highly individualized forms of instruction such as weekly learning plans, which has doubtless contributed to its high acceptance among teachers. The model seems practicable because it can be implemented to differing degrees and with differing focuses; it is flexible enough to be adapted to different contexts and conditions (e.g., different schools, classes, etc.). From the perspective of instructional research, it is also worth noting that the risk of negative effects on academic outcomes - as have been found for some radical concepts of "open education" (Giaconia \& Hedges, 1982; Gruehn, 2000; Lüders \& Rauin, 2004) - is limited: unlike radical reform concepts, the ETL model includes forms of direct instruction, which numerous empirical studies have shown to play an important role in student learning (see, e.e., Brophy, 1999; Helmke, 2009).

Given the ETL model's positive effects on student perceptions and experiences of instruction - and in view of findings from international empirical studies demonstrating positive effects of student-oriented instruction and good teacher-student relations (Cornelius-White, 2007) - one potential point of intervention for developing teacher expertise in the culture of teaching and learning would therefore be to encourage the more widespread implementation of the ETL reform model. The model can also be regarded as offering useful strategies for dealing with heterogeneous classes. In view of the planned or already realized move away from special classes and toward the inclusion of special needs students in mainstream education and continuing immigration (in Switzerland and elsewhere), this heterogeneity is bound to increase in the future. Whereas the literature criticizes the unreasonably high expectations and "euphoric hopes" associated with didactic concepts of withinclass differentiation (Trautmann \& Wischer, 2008), ETL seems to offer a practicable approach that stands the empirical test, having demonstrably positive effects on students' experience of instruction and wellbeing, without negative effects on educational outcomes. However, the data suggest that although teachers' implementation of the ETL model has to date (positively) influenced the culture of communication and support and extended their repertoire of teaching methods, there has been little change in aspects of mathematics-specific instruction in the narrow sense (e.g., 
the level of cognitive and mathematical challenge; provision for independent and discursive approaches to challenging problems). There thus seems to be room for improvement in the specific context of the didactics of mathematics.

Consequently, the culture of objectives, materials and tasks in Swiss mathematics classrooms is rather average in international comparison in several respects (level of mathematical content, characteristics of the problems set and the way they are worked on in lessons). Analyses of the Swiss Video Study data revealed considerable differences across school types in the German- and French-speaking parts of the country. Data from the Italian-speaking part of the country, where students are not tracked to separate secondary school types, but streamed within schools according to their ability in certain subjects, show that these differences are only partly the result of teachers adapting the level of challenge to better meet their students' cognitive needs: In the Italian-speaking region, observer ratings of cognitive activation did not differ significantly across lessons at the two achievement levels (Waldis et al., 2010b). It thus seems reasonable to surmise that the differences are also partly attributable to the teachers' training and responsibilities (see section "Characteristics of Swiss Mathematics Instruction in International Comparison"): In contrast to the Italian-speaking part of Switzerland, where the teachers at both levels receive the same training (Pauli \& Reusser, 2010a), almost all of the lessons videotaped in the least academically demanding schools in the German-speaking part of the country were taught by "all-rounders" with no university-level training in mathematics, whose teaching commitments included various subjects beside mathematics. Given these teachers' rather modest mathematical knowledge base and the scarce time they have to prepare lessons, the implementation of didactically more demanding models, as is called for in the current literature, does not seem practicable. Since the data were collected, teacher training at tertiary level has been restructured to place a much stronger focus on content knowledge and pedagogical content knowledge, meaning more of a subject focus in teaching responsibilities. It remains to be seen how these changes will influence the culture of materials and tasks in Swiss mathematics classrooms.

In terms of instructional development, Swiss teachers evidently have a pragmatic approach to instructional reform initiatives. As the principles of Hans Aebli's psychological didactics can be assumed to have an important influence on teaching practice at least in the German-speaking region of Switzerland, this should not come as any surprise. In Aebli's approach, which is rooted in cognitive psychology (Baer, Fuchs, Füglister, Reusser, \& Wyss, 2006), didactic decisions are based on not the surface-level characteristics of instruction, but on the deeper level of the quality of student learning processes (see also Oser \& Baeriswyl, 2001). Teachers in the German-speaking part of Switzerland can thus be expected to have a learning process orientation that is manifested, for example, in a pragmatic approach to different forms of instruction and social interaction in the classroom. In contrast to what is sometimes suggested in the current discussion of "constructivist learning environments" (see Tobias \& Duffy, 2009), Aebli did not consider teacher guidance and support of learning activities to be at odds with a constructivist understanding of learning. For Aebli, teacher-guided instructional dialogue was a 
key element, if not the key element, of cognitively guided instruction based on a constructivist understanding of teaching and learning. Extending the repertoire of teaching methods to include forms that grant students more self-direction and autonomy is, however, certainly compatible with Aebli's focus on student learning processes, although Aebli himself paid little attention to these aspects in his own work (Pauli, 2006).

One clear indication that teachers in German-speaking Switzerland have a learning process orientation is that the Swiss Video Study found no systematic relationship between reform-oriented instructional practice in terms of the organization of learning activities (opportunities for self-directed learning) and constructivistoriented beliefs about teaching and learning. In contrast, a constructivist orientation correlated positively with the reported frequency of opportunities for independent problem solving (Pauli et al., 2007) - in other words, with an instructional feature that focuses more on intended student learning processes than on the surface structure of instruction. This learning process orientation offers a good basis for instructional development, both from the perspective of general didactics and in the context of mathematics-specific conceptualizations of challenging, cognitively activating, and adaptive instruction. It is important to capitalize on Swiss mathematics teachers' learning process orientation through innovative forms of in-service training and instructional development that are congruent with their subjective theories of teaching and learning.

\section{References}

Aebli, H. (1951). Psychologische Didaktik. Didaktische Auswertung der Psychologie von Jean Piaget. Stuttgart: Klett.

Aebli, H. (1961). Grundformen des Lehrens. Stuttgart: Klett.

Aebli, H. (1983). Zwölf Grundformen des Lehrens. Stuttgart: Klett-Cotta.

Affolter, W., Beerli, G., Hurschler, H., Jaggi, B., Jundt, W., Krummenacher, R., et al. (2006). mathbu.ch. Impulse zur Mathematikdidaktik. Bern: BLMV.

Baer, M., Fuchs, M., Füglister, P., Reusser, K., \& Wyss, H. (Eds.). (2006). Didaktik auf psychologischer Grundlage. Von Hans Aeblis kognitionspsychologischer Didaktik zur modernen Lehrund Lernforschung. Bern: H.E.P.

Baumert, J., \& Kunter, M. (2006). Stichwort: Professionelle Kompetenz von Lehrpersonen. Zeitschrift für Erziehungswissenschaft, 9(4), 469-520.

Besser, M., \& Krauss, S. (2009). Zur Professionalität als Expertise. In O. Zlatkin-Troitschanskaia, K. Beck, D. Sembill, R. Nickolaus, \& R. Mulder (Eds.), Lehrprofessionalität-Bedingungen, Genese, Wirkungen und ihre Messung (pp. 71-82). Weinheim: Beltz.

Blömeke, S., Kaiser, G., \& Lehmann, R. (Eds.). (2008). Professionelle Kompetenz angehender Lehrerinnen und Lehrer. Wissen, Überzeugungen und Lerngelegenheiten deutscher Mathematikstudierender und-referendare. Münster: Waxmann.

Blömeke, S., \& Müller, C. (2008). Zum Zusammenhang von Allgemeiner Didaktik und LehrLernforschung im Unterrichtsgeschehen. In M. A. Meyer, M. Prenzel, \& S. Hellekamps (Eds.), Perspektiven der Didaktik (Zeitschrift für Erziehungwissenschaft, Sonderheft 9/2008 (pp. 239-258). Wiesbaden: VS Verlag für Sozialwissenschaften.

Brophy, J. (1999). Teaching. Brüssel/Genf: IAE/IBE.

Brophy, J. (2006). Observational research on generic aspects of classroom teaching. In P. A. Alexander \& P. Winne (Eds.), Handbook of educational psychology (2nd ed., pp. 755-780). Mahwah, NJ: Erlbaum. 
Buff, A., Reusser, K., \& Pauli, C. (2010). Die Qualität der Lernmotivation in Mathematik auf der Basis freier Äusserungen: Welches Bild präsentiert sich bei Deutschschweizer Schüler/innen im 8. und 9. Schuljahr? In K. Reusser, C. Pauli, \& M. Waldis (Eds.), Unterrichtsgestaltung und Unterrichtsqualität - Ergebnisse einer internationalen und schweizerischen Videostudie zum Mathematikunterricht (pp. 253-278). Münster: Waxmann.

Clarke, D., Mesiti, C., O’Keefe, C., Xu, L. H., Jablonka, E., Mok, I. A. C., et al. (2007). Addressing the challenge of legitimate international comparisons of classroom practice. International Journal of Educational Research, 46, 28-293.

Clausen, M., Reusser, K., \& Klieme, E. (2003). Unterrichtsqualität auf der Basis hoch-inferenter Unterrichtsbeurteilungen. Ein Vergleich zwischen Deutschland und der deutschsprachigen Schweiz. Unterrichtswissenschaft, 31(2), 122-141.

Cornelius-White, J. (2007). Learner-centered teacher-student relationships are effective: A metaanalysis. Review of Educational Research, 77(1), 113-143.

Croci, A., Imgrüth, P., Landwehr, N., \& Spring, K. (1995). ELF - ein Projekt macht Schule. Aarau: NWEDK.

Fend, H. (1998). Qualität im Bildungswesen. Schulforschung zu Systembedingungen, Schulprofilen und Lehrerleistung. Weinheim: Juventa.

Fend, H. (2002). Mikro- und Makrofaktoren eines Angebot-Nutzungsmodells von Schulleistungen. Zum Stellenwert der Pädagogischen Psychologie bei der Erklärung von Schulleistungsunterschieden verschiedener Länder. Zeitschrift für Pädagogische Psychologie, 16(3/4), 141-149.

Fend, H. (2008). Schule gestalten. Systemsteuerung, Schulentwicklung und Unterrichtsqualität. Wiesbaden: VS Verlag für Sozialwissenschaften.

Giaconia, R. M., \& Hedges, L. V. (1982). Identifying features of effective open education. Review of Educational Research, 52(4), 579-602.

Givvin, K. B., Hiebert, J., Jacobs, J., Hollingsworth, H., \& Gallimore, R. (2005). Are there national patterns of teaching? Evidence from the TIMSS 1999 video study. Comparative Education Review, 49(3), 311-343.

Givvin, K. B., Jacobs, J., Hollingsworth, H., \& Hiebert, J. (2009). What is effective mathematics teaching? International educators' judgments of mathematics lessons from the TIMSS 1999 video study. In J. Cai, A. Kaiser, B. Perry, \& N.-Y. Wong (Eds.), Effective mathematics teaching from teachers' perspectives: National and cross-national studies (pp. 37-69). Rotterdam: Sense Publishers.

Gruehn, S. (2000). Unterricht und schulisches Lernen. Schüler als Quellen der Unterrichtsbeschreibung. Münster: Waxmann.

Helmke, A. (2009). Unterrichtsqualität und Lehrerprofessionalität. Diagnose, Evaluation und Verbesserung des Unterrichts. Seelze-Velber: Kallmeyer/Klett.

Helmke, A., \& Weinert, F. E. (1997). Bedingungsfaktoren schulischer Leistung. In F. E. Weinert (Ed.), Psychologie des Unterrichts und der Schule (= Enzyklopädie der Psychologie, Themenbereich D, Serie I, Bd.3) (pp. 71-176). Göttingen: Hogrefe.

Hiebert, J., Gallimore, R., Garnier, H., Givvin, K. B., Hollingsworth, H., \& Jacobs, J. (2003). Teaching mathematics in seven countries. Results from the TIMSS 1999 video study. Washington, DC: U.S. Department of Education, National Center for Education Studies.

Hugener, I., \& Krammer, K. (2010). Differenzierende Massnahmen zur Individualisierung des Unterrichts. In K. Reusser, C. Pauli, \& M. Waldis (Eds.), Unterrichtsgestaltung und Unterrichtsqualität - Ergebnisse einer internationalen und schweizerischen Videostudie zum Mathematikunterricht (pp. 91-106). Münster: Waxmann.

Klieme, E., Pauli, C., \& Reusser, K. (2009). The pythagoras study: Investigating effects of teaching and learning in Swiss and German mathematics classrooms. In T. Janik \& T. Seidel (Eds.), The power of video studies in investigating teaching and learning in the classroom (pp. 137-160). Münster: Waxmann.

Klieme, E., \& Rakoczy, K. (2003). Unterrichtsqualität aus Schülerperspektive: Kulturspezifische Profile, regionale Unterschiede und Zusammenhänge mit Effekten von Unterricht. In 
J. Baumert, C. Artelt, E. Klieme, M. Neubrand, M. Prenzel, U. Schiefele, W. Schneider, K.-J. Tillmann, \& M. Weiss (Eds.), PISA 2000 - Ein differenzierter Blick auf die Länder der Bundesrepublik Deutschland (pp. 333-359). Opladen: Leske + Budrich.

Klieme, E., \& Rakoczy, K. (2008). Empirische Unterrichtsforschung und Fachdidaktik. Zeitschrift für Pädagogik, 54(2), 222-237.

Krammer, K. (2009). Individuelle Lernunterstützung in Schülerarbeitsphasen. Eine videobasierte Analyse des Unterstützungsverhaltens von Lehrpersonen im Mathematikunterricht. Münster: Waxmann.

Kunter, M., Dubberke, T., Baumert, J., Blum, W., Brunner, M., Jordan, A., et al. (2006). Mathematikunterricht in den PISA-Klassen 2004: Rahmenbedingungen, Formen und LehrLernprozesse. In PISA-Konsortium-Deutschland (Ed.), PISA 2003. Untersuchungen zur Kompetenzentwicklung im Verlauf eines Schuljahrs (pp. 161-194). Münster: Waxmann.

Kunter, M., Klusmann, U., \& Baumert, J. (2009). Professionelle Kompetenz von Mathematiklehrkräften: Das COACTIV-Modell. In O. Zlatkin-Troitschanskaia, K. Beck, D. Sembill, R. Nickolaus, \& R. Mulder (Eds.), Lehrprofessionalität - Bedingungen, Genese, Wirkungen und ihre Messung (pp. 153-179). Weinheim: Beltz.

Lipowsky, F., Rakoczy, K., Pauli, C., Drollinger-Vetter, B., Klieme, E., \& Reusser, K. (2009). Quality of geometry instruction and its short-term impact on students' understanding of the Pythagorean theorem. Learning and Instruction, 19(6), 527-537.

Lipowsky, F., Thussbas, C., Klieme, E., Reusser, K., \& Pauli, C. (2003). Professionelles Lehrerwissen, selbstbezogene Kognitionen und wahrgenommene Schulumwelt - Ergebnisse einer kulturvergleichenden Studie deutscher und schweizerischer Mathematiklehrer. Unterrichtswissenschaft, 31(3), 206-237.

Lüders, M., \& Rauin, U. (2004). Unterrichts- und Lehr-Lern-Forschung. In W. Helsper \& J. Böhme (Eds.), Handbuch für Schulforschung (pp. 691-719). Wiesbaden: VS Verlag Sozialwissenschaften.

Messner, R., \& Reusser, K. (2006). Aeblis Didaktik auf psychologischer Grundlage im Kontext der zeitgenössischen Didaktik. In M. Baer, M. Fuchs, P. Füglister, K. Reusser, H. Wyss (Eds.), Didaktik auf psychologischer Grundlage. Von Hans Aeblis kognitionspsychologischer Didaktik zur modernen Lehr- und Lernforschung (pp. 52-73). Bern: H.E.P.

Moser, U., \& Notter, P. (2000). Schulische Leistungen im internationalen Vergleich. Ausgewählte schweizerische Ergebnisse aus internationalen Leistungsvergleichen bei Kindern, Jugendlichen und Erwachsenen (hrsg. von der EDK). Bern: EDK.

Moser, U., Ramseier, E., Keller, C., \& Huber, M. (1997). Schule auf dem Prüfstand. Eine Evaluation der Sekundarstufe I auf der Grundlage der "Third international mathematics and science study”. Chur: Rüegger.

Oser, F., \& Baeriswyl, F. J. (2001). Choreographies of teaching: Bridging instruction to learning. In V. Richardson (Ed.), Handbook of research on teaching (4th ed., pp. 1031-1065). New York: Macmillan.

Pauli, C. (2006). "Fragend-entwickelnder Unterricht" aus der Sicht der soziokulturalistisch orientierten Unterrichtsgesprächsforschung. In M. Baer, M. Fuchs, P. Füglister, K. Reusser, \& H. Wyss (Eds.), Didaktik auf psychologischer Grundlage. Von Aeblis kognitionspsychologischer Didaktik zur modernen Lehr-Lernforschung (pp. 192-206). Bern: H.E.P.

Pauli, C., \& Reusser, K. (2003). Unterrichtsskripts im schweizerischen und im deutschen Mathematikunterricht. Unterrichtswissenschaft, 31(3), 238-272.

Pauli, C., \& Reusser, K. (2009). Zum Einfluss von Professionalität auf die Qualität von LehrLern-Prozessen. In O. Zlatkin-Troitschanskaia, K. Beck, D. Sembill, R. Nickolaus, \& R. Mulder (Eds.), Lehrprofessionalität - Bedingungen, Genese, Wirkungen und ihre Messung (pp. 679-690). Weinheim: Beltz.

Pauli, C., \& Reusser, K. (2010a). Selbst- und Unterrichtswahrnehmung der Lehrpersonen. In K. Reusser, C. Pauli, \& M. Waldis (Eds.), Unterrichtsgestaltung und Unterrichtsqualität Ergebnisse einer internationalen und schweizerischen Videostudie zum Mathematikunterricht (pp. 143-170). Münster: Waxmann. 
Pauli, C., \& Reusser, K. (2010b). Unterrichtsgestaltung im internationalen Vergleich: Die Schweiz in der TIMSS 1999 Videostudie. In K. Reusser, C. Pauli, \& M. Waldis (Eds.), Unterrichtsgestaltung und Unterrichtsqualität - Ergebnisse einer internationalen und schweizerischen Videostudie zum Mathematikunterricht (pp. 57-89). Münster: Waxmann.

Pauli, C., Reusser, K., \& Grob, U. (2007). Teaching for understanding and/or self-regulated learning? A video-based analysis of reform-oriented mathematics instruction in Switzerland. International Journal of Educational Research, 46(5), 294-305.

Pauli, C., Reusser, K., \& Grob, U. (2010). Reformorientierter Mathematikunterricht in der Deutschschweiz. In K. Reusser, C. Pauli, \& M. Waldis (Eds.), Unterrichtsgestaltung und Unterrichtsqualität - Ergebnisse einer internationalen und schweizerischen Videostudie zum Mathematikunterricht (pp. 309-339). Münster: Waxmann.

Pauli, C., Reusser, K., Waldis, M., \& Grob, U. (2003). "Erweiterte Lehr- und Lernformen" im Mathematikunterricht der Deutschschweiz. Unterrichtswissenschaft, 31(4), 291-320.

Petko, D., Krammer, K., Pauli, C., \& Reusser, K. (2010). Gibt es eine spezifisch schweizerische Perspektive auf Unterrichtsqualität? - Ergebnisse aus Diskussionen internationaler Expertengruppen. In K. Reusser, C. Pauli, \& M. Waldis (Eds.), Unterrichtsgestaltung und Unterrichtsqualität - Ergebnisse einer internationalen und schweizerischen Videostudie zum Mathematikunterricht (pp. 123-142). Münster: Waxmann.

Philipp, R. A. (2007). Mathematics teachers' beliefs and affect. In F. K. Lester (Ed.), Second handbook of research on mathematics teaching an learning (pp. 257-315). Charlotte, NC: NCTM/Information Age Publishing.

Rakoczy, K. (2008). Motivationsunterstützung im Mathematikunterricht. Unterricht aus der Perspektive von Lernenden und Beobachtern. Münster: Waxmann.

Reinisch, H. (2009). "Lehrerprofessionalität" als theoretischer Term. In O. ZlatkinTroitschanskaia, K. Beck, D. Sembill, R. Nickolaus, \& R. Mulder (Eds.), Lehrprofessionalität - Bedingungen, Genese, Wirkungen und ihre Messung (pp. 33-43). Weinheim: Beltz.

Reusser, K. (2008). Empirisch fundierte Didaktik - didaktisch fundierte Unterrichtsforschung. Eine Perspektive zur Neuorientierung der Allgemeinen Didaktik. In M. A. Meyer, M. Prenzel, \& S. Hellekamps (Eds.), Perspektiven der Didaktik (Zeitschrift für Erziehungwissenschaft, Sonderheft 9/2008) (pp. 219-237). Wiesbaden: VS Verlag für Sozialwissenschaften.

Reusser, K. (2009). Unterricht. In S. Andresen, R. Casale, T. Gabriel, R. Horlacher, S. Larcher Klee, \& J. Oelkers (Eds.), Handwörterbuch Erziehungswissenschaft (pp. 881-896). Weinheim: Beltz.

Reusser, K., \& Pauli, C. (1999, September). Unterricht beobachten und verstehen. Strategien zur Rekonstruktion des Kontextes in der videobasierten Unterrichtsforschung, am Beispiel der Video-Studie "Mathematiklernen und Mathematikleistungen in unterschiedlichen Unterrichtskulturen" (Understanding classroom teaching. Reconstructing the systemic context of instruction in video-based classroom research). Paper presented at the 7 . Fachtagung der Fachgruppe Pädagogische Psychologie der DGPs, Symposium "Videogestützte Unterrichtsforschung". Fribourg.

Reusser, K., \& Pauli, C. (2003). Mathematikunterricht in der Schweiz und in weiteren sechs Ländern. Bericht über die Ergebnisse einer internationalen und schweizerischen VideoUnterrichtsstudie. Doppel-CD-ROM. Zürich: Universität Zürich.

Reusser, K., Pauli, C., \& Elmer, A. (2011). Berufsbezogene Überzeugungen von Lehrerinnen und Lehrern. In E. Terhart, H. Bennewitz, \& M. Rothland (Eds.), Handbuch der Forschung zum Lehrerberuf (pp. 434-451). Münster: Waxmann.

Reusser, K., \& Pauli, C., \& Waldis, M. (Eds.). (2010). Unterrichtsgestaltung und Unterrichtsqualität - Ergebnisse einer internationalen und schweizerischen Videostudie zum Mathematikunterricht. Münster: Waxmann.

Richardson, V., \& Placier, P. (2001). Teacher change. In V. Richardson (Ed.), Handbook of research on teaching (4th ed., pp. 905-947). Washington, DC: American Educational Research Association. 
Seidel, T., \& Shavelson, R. J. (2007). Teaching effectiveness research in the past decade: The role of theory and research design in disentangling meta-analysis results. Review of Educational Research, 77(4), 454-499.

Stebler, R., \& Reusser, K. (2000). Progressive, classical or balanced - A look at mathematical learning environments in Swiss-German lower-secondary schools. Zentralblatt für die Didaktik der Mathematik, 32(1), 1-10.

Stefanou, C. R., Perencevich, K. C., DiCintio, M., \& Turner, J. C. (2004). Supporting autonomy in the classroom: Ways teachers encourage student decision making and ownership. Educational Psychologist, 39(2), 97-110.

Stigler, J. W. (1998). Video surveys: New data for the improvement of classroom instruction. In S. G. Paris \& H. M. Wellman (Eds.), Global prospects for education. Development, culture and schooling (pp. 129-168). Washington, DC: American Psychological Association.

Stigler, J. W., \& Hiebert, J. (1999). The teaching gap. New York: Free Press.

Tobias, S., \& T. Duffy (Eds.). (2009). Constructivist instruction: Success or failure? New York: Routledge.

Trautmann, M., \& Wischer, B. (2008). Das Konzept der Inneren Differenzierung eine vergleichende Analyse der Diskussionen der 1970er Jahre mit dem aktuellen Heterogenitätsdiskurs. In M. A. Meyer, M. Prenzel, \& S. Hellekamps (Eds.), Perspektiven der Didaktik (Zeitschrift für Erziehungwissenschaft, Sonderheft 9/2008) (pp. 159-172). Wiesbaden: VS Verlag für Sozialwissenschaften.

Turner, J. C., Christensen, A., \& Meyer, D. K. (2009). Teachers' beliefs about student learning and motivation. In L. J. Saha \& A. G. Dworkin (Eds.), International handbook of research on teachers and teaching (pp. 361-371). Boston: Springer.

Wagenschein, M. (2008). Verstehen lehren: Genetisch - sokratisch - exemplarisch (4th ed.). Weinheim: Beltz.

Waldis, M., Grob, U., Pauli, C., \& Reusser, K. (2010a). Der Einfluss der Unterrichtsgestaltung auf Fachinteresse und Mathematikleistung. In K. Reusser, C. Pauli, \& M. Waldis (Eds.), Unterrichtsgestaltung und Unterrichtsqualität - Ergebnisse einer internationalen und schweizerischen Videostudie zum Mathematikunterricht (pp. 209-251). Münster: Waxmann.

Waldis, M., Grob, U., Pauli, C., \& Reusser, K. (2010b). Der schweizerische Mathematikunterricht aus der Sicht von Schülerinnen und Schülern und in der Perspektive hochinferenter Beobachterurteile. In K. Reusser, C. Pauli, \& M. Waldis (Eds.), Unterrichtsgestaltung und Unterrichtsqualität - Ergebnisse einer internationalen und schweizerischen Videostudie zum Mathematikunterricht (pp. 171-208). Münster: Waxmann.

Wittmann, E. (1981). Grundfragen des Mathematikunterrichts (6th ed.). Braunschweig: Vieweg.

Zahner Rossier, C. (2005). PISA 2003: Kompetenzen für die Zukunft. Zweiter nationaler Bericht. Neuchâtel/Bern: Bundesamt für Statistik (BFS)/EDK.

Zahner Rossier, C., Berweger, S., Brühwiler, C., Holzer, T., Mariotta, M., Moser, U., et al. (2004). PISA 2003: Kompetenzen für die Zukunft. Erster nationaler Bericht. Neuchâtel/Bern: Bundesamt für Statistik (BFS) und Schweizerische Konferenz der kantonalen Erziehungsdirektoren (EDK).

Zahner Rossier, C., \& Holzer, T. (2007). PISA 2006. Kompetenzen für das Leben - Schwerpunkt Naturwissenschaften. Nationaler Bericht. Neuenburg: Bundesamt für Statistik. 